\title{
SISTEM INFORMASI PENGAMBILAN KEPUTUSAN DENGAN e-Vote ONLINE
}

\author{
Putu Gde Sukarata ${ }^{1}$, I Gede Suputra Widharma ${ }^{2}$, I Made Wijaya Kusuma ${ }^{3}$ \\ ${ }^{1}$ Program Studi Manajemen Informatika, JurusanTeknik Elektro, Politeknik Negeri Bali \\ Kampus Bukit Jimbaran, Kuta, Badung, Bali \\ ${ }^{2}$ Program Studi Teknik Otomasi, JurusanTeknik Elektro, Politeknik Negeri Bali \\ Kampus Bukit Jimbaran, Kuta, Badung, Bali \\ ${ }^{3}$ Fakultas Teknik, Prodi Teknik Industri, Universitas Mahendradatta \\ Kampus Pusat Peguyangan, Badung, Bali \\ Email: sukarata@pnb.ac.id, suputra.widharma@gmail.com, mdwikus@yahoo.com
}

\begin{abstract}
Abstrak - Perkembangan dunia komputer yang semakin kompleks mendorong setiap individu ataupun kelompok, mau tidak mau harus menerapkan komputer dalam segala aktivitas. Mau disadari atau tidak setiap sistem yang ada, seakan kurang lengkap kalau masih menggunakan model tradisional ataupun model secara manual. Disamping banyak energi sumber daya yang terbuang sia-sia juga dari segi fiinansial tentunya menjadikan biaya yang tinggi. Seperti kita ketahui setiap perkembangan teknologi informasi semakin dalam mempengaruhi sistem informasi yang ada. Sistem informasi yang masih klasik seakan sebuah sistem yang kuno dan ketinggalan zaman. Seiring dengan perkembangan teknologi informasi tersebut, terus berpacu dengan waktu. Selain mempengaruhi sistem informasi yang ada juga mempengaruhi kehidupan sehari-hari. Gaya hidup mulai berubah seiring dengan produk-produk teknologi informasi yang semakin menjamur setiap saat. Seluruh komponen masyarakat seakan wajib belajar dan minimal tahu menggunakan teknologi ini. Setiap permasalahan yang berkembang serta penyajian informasi yang semakin usang mendudukkan komputer sebagai alat yang harus dimasukkan ke dalam sistem informasi

Sistem Informasi yang disajikan berbagai bentuk ragamnya, diantaranya adalah mempublikasikannya ke dunia maya (internet). Internet tidak memiliki batas waktu, ruang dan tempat sehingga kapan saja orang dapat mengaksesnya.

Kendala yang sering dihadapi dalam pembuatan sistem informasi berbasis web adalah waktu akses yang diperlukan untuk menampilkan isi dari web tersebut. Pembuatan sistem informasi berupa rekapan kegiatan rapat yang tidak menemukan kata mufakat berbasis web ini dirancang dengan menggunakan beberapa aplikasi yang mendukung dan menggunakan beberapa format gambar dan animasi yang nantinya dapat diakses dengan mudah dan cepat.
\end{abstract}

Kata kunci: model, sistem klasik, teknologi

\begin{abstract}
The development of computer system nowdays is getting faster and complex, to push everyone using computer in daily activity. We realize that by using manual system is not enough recently so we need computer to compile our file. By using manual system just waste our energy and our finance. The result of this system, we spend much money. As we know the development of information technology (IT) has got influence to our information system. The classical system of information is getting worse and an old fashion. Beside to influent its information of technology it has got an influence to our daily life, our life style will be change according to the developing of IT product. Everybody should understand to use or operate this technology. Every problem that appear and old fashion information system, computer is as one of devices should be entered to information system.

Many kinds to publish our service and product via internet. Because internet not know about limited of time, limited of place dan limited of space. Everytime we can reach them and surfing with browser to find a lot of information.A treatment usualy we get publish our site is how much time the audien can reach our site and they dont necesery much need time to see our page. We can used a few aplication to built a webpage that they can make a page can reach as soon as possible. And we can used a few format of image and animation then make the audien no need more time to search our information.
\end{abstract}

Keywords: model, classic system, technology 


\section{PENDAHULUAN}

Perkembangan teknologi di bidang informasi dari tahun ke tahun sudah mengalami kemajuan yang sangat pesat, terutama teknologi informasi dengan media internet pada era globalisasi ini. Media internet digunakan sebagai salah satu tempat untuk mencari informasi yang lengkap dan terbaru. Disamping itu, internet tidak mengenal batas, tempat/ruang dan waktu. Banyaknya informasi yang di unggah dan di unduh telah membuat internet juga menjadi media untuk publikasi dan lain sebagainya.

Kemampuan dari internet ini kemudian membuat institusi-institusi memanfaatkannya didalam pengolahan informasi data dirinya, baik sebagai sarana interaksi antar komponen di dalam institusi tersebut, juga dalam menciptakan komunikasi dua arah dengan pihak lainnya diluar institusi tersebut.

Yang pertama merujuk kepada Medanmerdeka.com - Untuk membenahi manajemen kepegawain, Pemerintahan Provinsi Sumatera Utara (Pemprovsu) segera menerapkan sistem paperless (tanpa kertas) dalam pelayanan administrasi kepegawaian. Hal ini disampaikan Sekretaris Daerah Provinsi Sumatera Utara (Sekdaprovsu) Dr Ir Hj R Sabrina MSi saat membuka Rapat Kerja Kepegawaian antara Pemerintah Provinsi dengan Pemerintah Kabupaten/Kota se-Sumut, di Hotel Polonia Medan, Rabu (4/7/2018). "Pelayanan administrasi kepegawaian tanpa kertas merupakan wujud nyata dari reformasi birokrasi. Sistem ini kita aplikasikan dengan menggunakan teknologi yang diorganisasikan secara terpadu untuk dapat memecahkan masalah dan pengambilan keputusan secara online, akurat, real time dan berkaitan dengan manajemen kepegawaian,"ucap Sabrina, yang didampingi Asisten Ekonomi dan Pembangunan Ibnu S Hutomo.

Yang Kedua Mengintip "Parlemen Tanpa Kertas" di Korea Selatan Kompas.com 23/10/2015, 14:43 WIB Bagikan: Komentar Ketua MPR RI Zulkifli Hasan saat menyampaikan sambutan dalam acara pemberian penghargaan kepada 100 perusahaan terbaik, di Seoul, Korea Selatan, Kamis (22/10/2015). Powered by Telkomsel BlackBerry ${ }^{\circledR}$ Ketua MPR RI Zulkifli Hasan saat menyampaikan sambutan dalam acara pemberian penghargaan kepada 100 perusahaan terbaik, di Seoul, Korea Selatan, Kamis
(22/10/2015). Powered by Telkomsel BlackBerry®(Indra Akuntono) Penulis Indra Akuntono | EditorInggried Dwi Wedhaswary SEOUL, KOMPAS.com - Delegasi MPR RI berkesempatan menengok ruang sidang Parlemen Korea Selatan, di Seoul, seusai bertemu dengan Ketua Parlemen Korsel Chung Ui-hua, Jumat (23/10/2015). Ruang sidang parlemen Korsel itu ternyata serba digital atau biasa disebut sebagai "parlemen tanpa kertas." Sidang-sidang di Parlemen Korsel mulai tidak menggunakan kertas sejak 2005. Semua materi persidangan terkomputerisasi. Masyarakat juga dapat mengikuti, dan mengawasi jalannya pengambilan keputusan secara online.

Dengan merancang dan membuat Sistem Informasi Pengambilan Keputusan Dengan e-Vote Online dapat mengoptimalkan informasi tentang pengambilan keputusan secara cepat khususnya pelaksanaan dalam rapat ketika menemui ketidaksepakatan. Demikian juga dengan penggunaan kertas hampirlah minim (paper less) hal ini dapat dilakukan dimana saja mengingat sistem ini dapat digunakan secara online, disamping manfaat lainnya yaitu meminimalkan waktu rapat yang terkadang sampai berlarut-larut karena hal tersebut diatas.

\section{METODE PENELITIAN}

\section{Pengumpulan data}

Metode pengumpulan data pada penelitian ini menggunakan beberapa teknik pengumpulan data seperti :

\section{Metode Pengamatan Langsung}

(Observasi) : metode ini merupakan salah satu metode pengumpulan data yang efektif dimana dapat dilakukan dengan mengamati langsung objek atau kegiatan yang sedang berjalan/dilakukan, sehingga data yang dikumpulkan cenderung mempunyai kehandalan yang tinggi serta untuk mengecek keabsahan/kevalidan dari data yang diperoleh sebelumnya.

Metode Pengambilan Sampel : sampel yang akan digunakan adalah mahasiswa yang melakukan browsing ke prototipe ini, dimana setiap mahasiswa harus mengisi pilihan vote pada form sebelum dapat melihat informasi lebih lanjut dan disimpan didalam database. Sehingga secara statistik kita ketahui bahwa informasi yang disampaikan memang sudah benar sampai ke mahasiswa. 
2. Metode Perancangan Penelitian Kondisi Eksisting Pengambilan Keputusan Pemilihan Koordinator tingkat

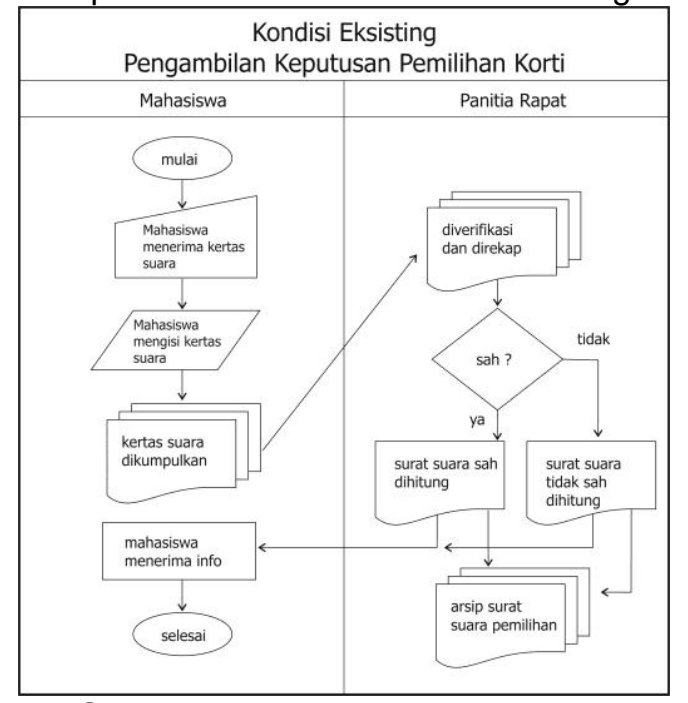

Gambar 1. Kondisi Eksisting Pemilihan Korti

Rancangan model data yang digunakan adalah Data Flow Diagram (DFD)

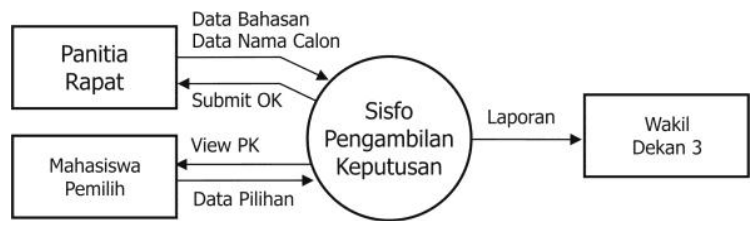

Gambar 2. DFD Konteks

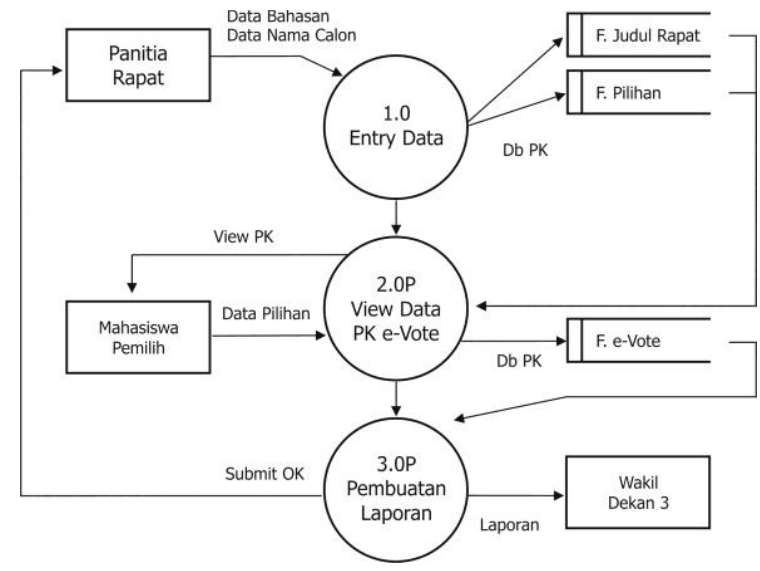

Gambar 3. DFD Zero

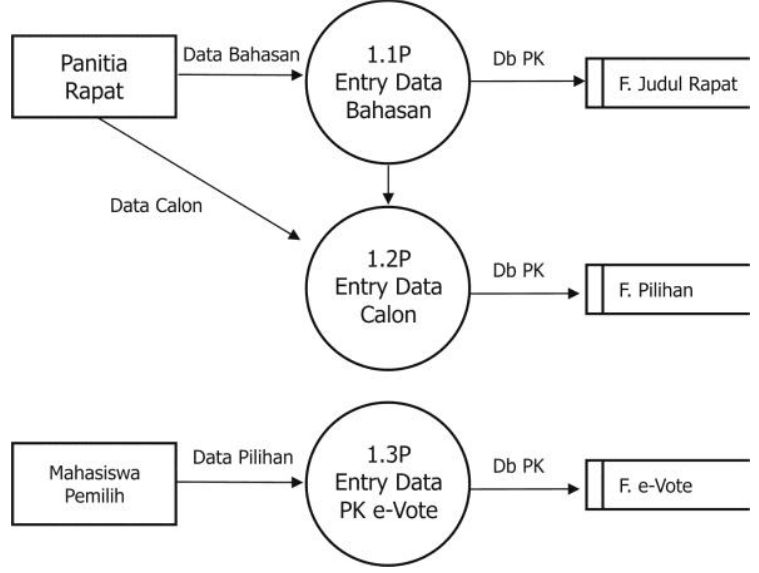

Gambar 4. DFD Detail

\section{Metode Perangkat Lunak}

Dalam mengimplementasikan prototipe yang akan dibuat ini, menggunakan program pengolah gambar seperti Photoshop dan CorelDraw untuk mengaplikasikan gambar/image yang akan ditampilkan. Photoshop memiliki banyak fitur dan performa yang lebih baik dalam mengolah gambar, diantaranya teknik membuat objek, manajemen layer, mengetik teks, filter, layer style, transformasi objek dan yang lainnya. Sedangkan CorelDraw memiliki tool freehand dan bezier yang lebih fleksibel dalam menggambar objek yang lebih rumit. Untuk layout design web page menggunakan Dreamweaver $M X$ yang memiliki jendela view code dan view design serta Macromedia Flash untuk mempercantik animasi. Sedangkan untuk database yang akan digunakan adalah dengan MySql yang tampilan formnya menggunakan bahasa pemrograman PHP. Bahasa pemrograman PHP dapat dijalankan pada server side yang artinya semua coding dapat dijalankan pada server, sedangkan yang tampil pada browser adalah hasilnya. Pengujian awal sistem yang dibuat dapat diketahui secara optimal mudah dan cepat diakses pada saat perancangan web page adalah dengan mengatur isi konten-konten yang ada didalamnya baik text ataupun gambar.

\section{HASIL DAN PEMBAHASAN}

\section{Image Header}

Dengan ukuran lebar 600px dan tinggi 100px pada sisi kiri, serta menggunakan mode color RGB dengan resolusi $72 \mathrm{dpi}$ menghasilkan kapasitas file sebesar 10918 bites dengan ekstenti format gambar jpg, dengan ukuran yang rata-rata selebar layar 
monitor hasil desain yang didapat adalah sangat kecil disebabkan karena penggunaan jumlah gambar sangat sedikit. Sehingga dapat lebih cepat mengakses website yang dibuat.

Hasil gambar yang didapat tidak terlalu lama untuk diakses sebab penggunaan image header ini akan ditampilkan diseluruh halaman web yang dirancang sehingga dalam men-download-nya cukup hanya satu kali saja untuk keseluruhan halaman yang akan ditampilkan.

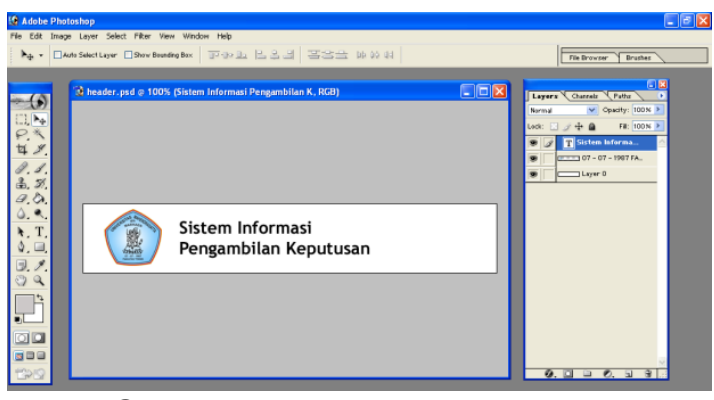

Gambar 5. Hasil Image Header

\section{Image Logo FT UnMar}

Pada desain image logo FT UnMar dibuat dengan ukuran lebar $75 \mathrm{px}$ dengan tinggi 75px, hasil didapatkan kapasitas gambar ini hanya 1900 bites perancangan logo ini disatukan dengan image header yang sudah dirancang.

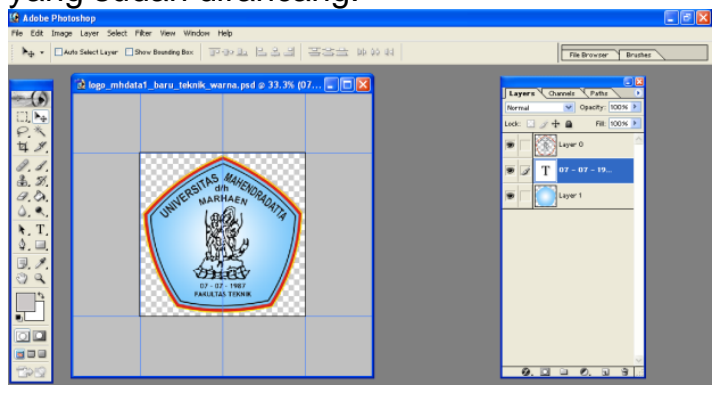

Gambar 6. Hasil Image Logo FT UnMar

\section{Image Footer}

Image footer dibuat dan disambungkan dengan gambar lain yang dikreasikan sehingga tampilan dapat lebih menarik. Dengan ukuran lebar 900px dan tinggi 75px yang relatif lebih kecil dari image header hasil yang didapat kapasitas gambar lebih besar disebabkan karena image footer ini berisi text dan background hitam, walaupun menggunakan mode color yang sama dengan image header yaitu format jpg.

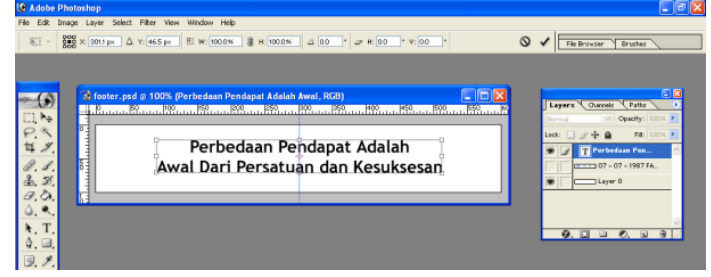

Gambar 7. Hasil Image Footer

\section{Animasi Logo UnMar}

Pembuatan animasi menggunakan Macromedia Flash ini sangatlah mudah, hanya menggunakan frame sebagai stage dari masing-masing gambar yang akan dijalankan. Beberapa efek dari macromedia flash ini sangat familiar digunakan sama halnya dengan mengolah animasi yang lain.

Animasi ini menghasilkan efek pencahayaan pada akhir frame sehingga logo UnMar ini seolah-olah disinari oleh cahaya yang mengenainya dimana cahaya tersebut berada dibelakang logo, efek yang digunakan adalah outer glow dengan ketajaman yang sangat kurang sehingga cahaya yang ditimbulkan juga nantinya tidak terang, tetapi agak kabur menyerupai kabut cahaya.

Hasil olahan di export ke format gambar GIF dengan resolusi yang sama dengan desain image menggunakan 72dpi.

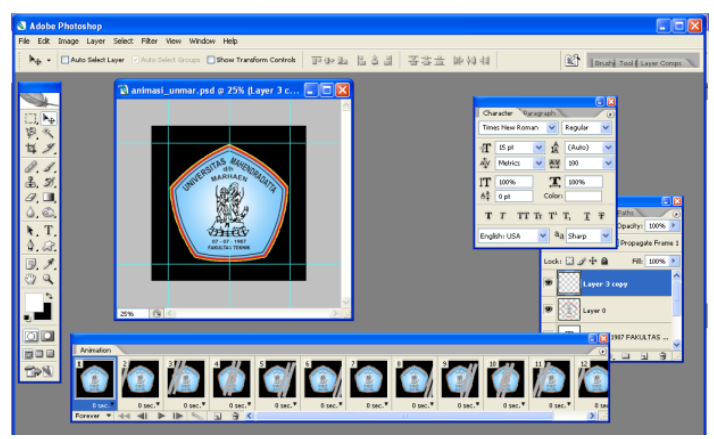

Gambar 8. Hasil Animasi Logo UnMar

\section{Animasi Button}

Pembuatan animasi button sangat mudah dengan menggunakan dua layer photoshop dengan dua kejadian up button dan kejadian over button 


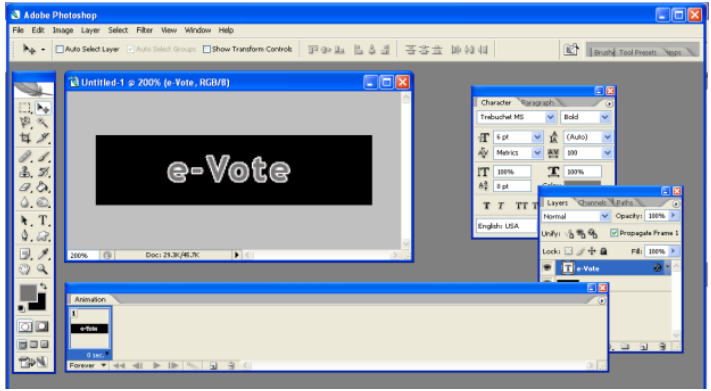

Gambar 9. Hasil Animasi Button

Kejadian up button adalah kejadian dimana tombol tersebut tidak dilalui mouse sedangkan kejadian over button adalah kejadian ketika button tersebut dilalui oleh mouse. Pada saat over button ini user dapat menekan tombol tersebut dan mengeksekusi coding yang ada didalamnya.

\section{Halaman Landing Page}

Setelah seluruh image dan animasi disiapkan maka dengan mudah kita akan me-layout-nya di deamweaver dengan ukuran lebar 800px dan tinggi yang berkesesuaian dengan banyaknya isi halaman. Tabel sangat diperlukan untuk melayout rancangan halaman web agar seluruh image dan animasi tetap berada di posisinya apabila nanti pemilih melakukan refresh ulang terhadap halaman yang tampil tersebut.

Landing page dari sistem ini merupakan halaman pertama yang tampil ketika website ini di akses dan secara default sudah berisi pokok bahasan yang akan di voting dengan pilihan yang sudah tersedia

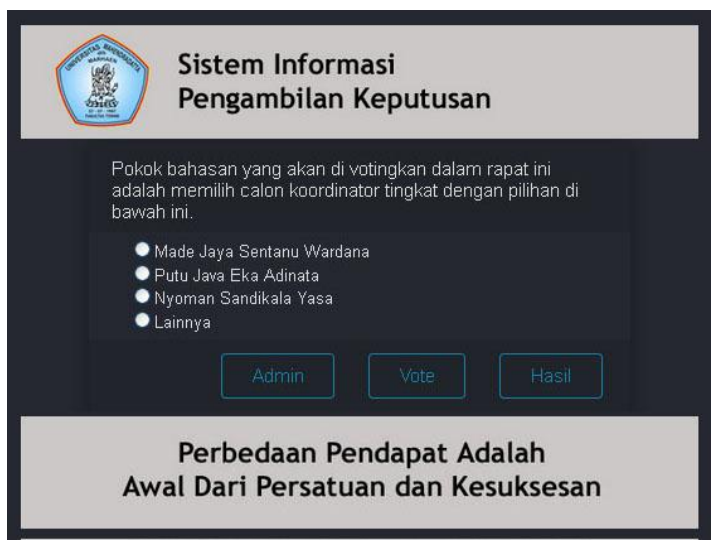

Gambar 10. Hasil Halaman Landing Page

Terdapat header page berisi logo FT UnMar dan teks penjelasan dari sistem informasi pengambilan keputusan dan footer page yang berisikan teks himbauan bahwa perbedaan pendapat adalah awal dari persatuan dan kesuksesan. Serta berisi 3 buah tombol yang mempunyai fungsi masing-masing, dimana tombol vote adalah kejadian pemilih ketika

akan memilih pilihan yang ada, tombol hasil hanya bisa dieksekusi oleh admin karena untuk menghindari terjadi kecurangan dalam pelaksanaan voting tersebut, untuk tombol admin dilakukan apabila terjadi perubahan pokok bahasan yang akan di voting serta perubahan pilihan ayang akan dilakukan.

Pada halaman login terdapat logo FT UnMar dengan dua buah teks line yang meminta memasukkan username atau berupa email yang sudah disiapkan begitu pula teks line yang berikutnya adalah harus memasukkan password. Kedua teks line ini harus mempunyai nilai yang sama dengan nilai yang sudah disiapkan. Jikalau terjadi ketidaksamaan nilai maka akan muncul pesan kesalahan pada form login ini berupa teks pesan bahwa memasukkan username dan password adalah salah, sehingga user yang bukan merupakan admin sistem tidak dapat masuk ke dalam sistem.

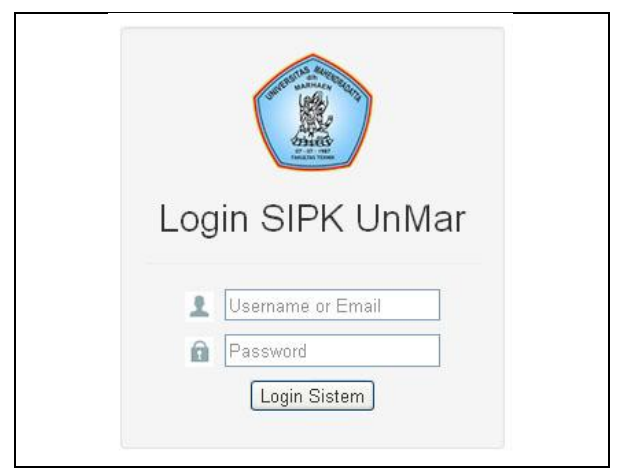

Gambar 11. Hasil Halaman Login 


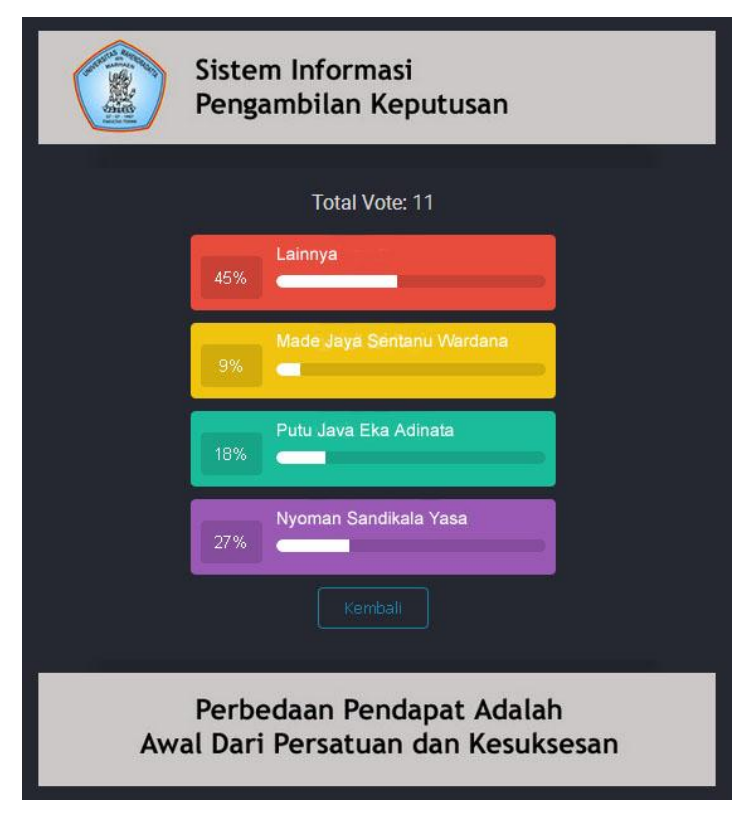

Gambar 12. Hasil Halaman eVote

Untuk pemilih yang sudah melakukan voting tidak dapat lagi memilih karena sudah tersetting waktu selama 1 hari dengan menggunakan satu perangkat, baik handphone atau pun komputer atau laptop. Ini dilakukan berdasarkan session yang dibaca oleh sistem sehingga pemilih tidak dapat melakukan voting lebih dari sekali. Setelah batas waktu sudah habis digunakan sesuai dengan kesepakatan maka admin dapat menekan tombol hasil untuk memunculkan seluruh voting yang masuk. Tampilan hasil voting disajikan berupa prosentase suara pemilih yang masuk dan dapat pula menampilkan pilihan lain yang merupakan suara abstain jika para pemilih tidak tertarik dengan pilihan yang disediakan.

\section{SIMPULAN DAN SARAN}

a. Dengan menggunakan program aplikasi Macromedia Dreamweaver sebagai layout dari webpage yang dibuat maka seluruh informasi pengambilan keputusan ini dapat dikelola dengan mudah sehingga format sistem informasi yang dibuat berbasis web ini dapat digunakan sebagai bank data untuk pelaporan hasil rapat berdasarkan voting secara online. Penyimpanan data tidak harus terpusat, tapi bisa diakses dari pusat, sehingga data yang diinputkan tidak ganda. Hal ini akan mendukung kevalidan data yang akan diinformasikan.

b. Dengan meminimalisir image atau gambar yang didesain pada halaman web serta menggunakan format gambar dengan ekstensi JPG yang mempunyai resolusi $72 \mathrm{dpi}$ maka waktu yang dibutuhkan dalam mengakses halaman tersebut akan menjadi lebih cepat (kurang lebih sekitar 13 detik untuk waktu akses pertama kali).

c. Sedangkan untuk dapat menjaga otoritas SIPK, maka sub institusi ini harus tetap berpayung pada SIM Institusi memanfaatkan fasilitas links yang tersedia..

\section{DAFTAR PUSTAKA}

Harianto Kristanto. Ir, 2004, Konsep dan Perancangan Database, Yogyakarta, ANDI

Pramono, 2004, Kolaburasi Flash, Dreamweaver dan PHP, ANDI, Yogyakarta

Prihatna, H., 2008, Kiat Praktis Menjadi Webmaster Profesional, PT. Elexmedia Komputindo, Jakarta

Simarmata, P., 2006, Basis Data, ANDI, Yogyakarta

Sullivan, 2002, Macromedia Flash 5, ANDI, Yogyakarta

Zanzad, 2005, Dreamweaver MX, INDAH, Surabaya

https://medanmerdeka.com/news/pelayanan -administrasi-tanpa-kertas-akanditerapkan/

Pelayanan Administrasi Tanpa Kertas Akan Diterapkan, Rabu, 4 Juli 2018 Pukul 18.39

http://simpegbkd.sumutprov.go.id/site/login 